\title{
Working
}

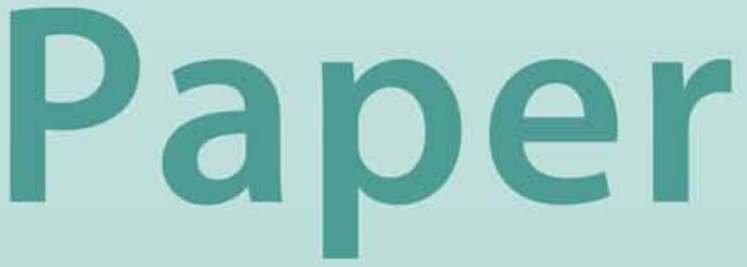




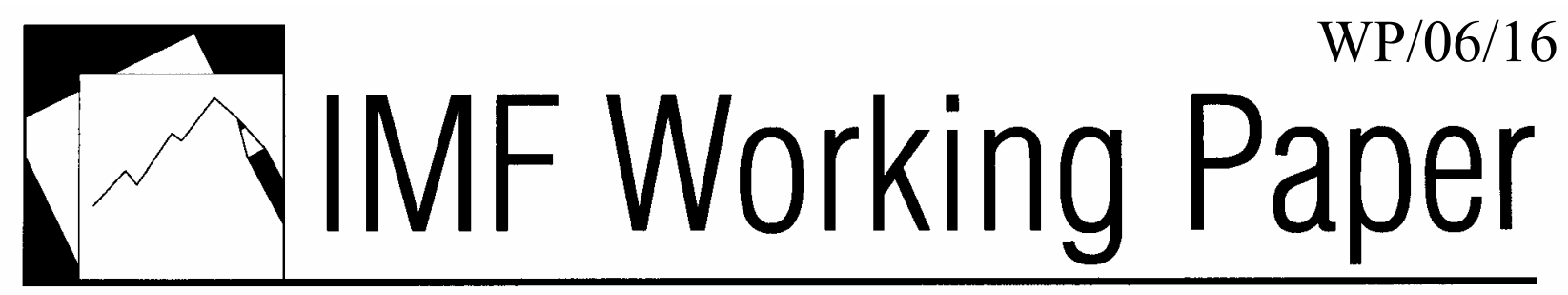

Fiscal Policy and Financial Markets

Bernardin Akitoby and Thomas Stratmann 


\title{
IMF Working Paper
}

Fiscal Affairs Department

\section{Fiscal Policy and Financial Markets}

\author{
Prepared by Bernardin Akitoby and Thomas Stratmann ${ }^{1}$ \\ Authorized for distribution by Gerd Schwartz
}

January 2006

\begin{abstract}
This Working Paper should not be reported as representing the views of the IMF. The views expressed in this Working Paper are those of the author(s) and do not necessarily represent those of the IMF or IMF policy. Working Papers describe research in progress by the author(s) and are published to elicit comments and to further debate.

This paper introduces fiscal policy in a model of sovereign risk spreads ("spreads"). Using panel data from emerging market countries, we find that reductions in public expenditure are a more powerful tool for reducing spreads than increases in revenues. Specifically, cuts in current spending lower spreads by more than cuts in investment spending, and they also lower spreads by more than increases in revenue. We also show that debt-financed current spending increases sovereign risk by more than tax-financed current spending, suggesting that international investors have some preference for the latter. In line with the empirical literature on the determinants of spreads, we find that liquidity and solvency indicators, as well as macroeconomic fundamentals, are also important determinants of spreads.
\end{abstract}

JEL Classification Numbers: E62, G15, H39, H63

Keywords: Fiscal policy, sovereign risk, spreads, bond markets, emerging markets

Author(s) E-Mail Address: bakitoby@imf.org; tstratma@gmu.edu

\footnotetext{
${ }^{1}$ This paper was written when Thomas Stratmann (George Mason University) was a visiting scholar with the IMF's Fiscal Affairs Department in early 2005. We would like to thank Larry Cui for the excellent research support. For very helpful comments, we wish to thank Gerd Schwartz, Antonio Spilimbergo, Robert Flood, David Hauner, and Anna Ilyina. We are also grateful for helpful suggestions by participants of the conference on "New Perspectives on Fiscal Sustainability” held at Goethe Universität Frankfurt, Germany, in October 2005.
} 
Contents

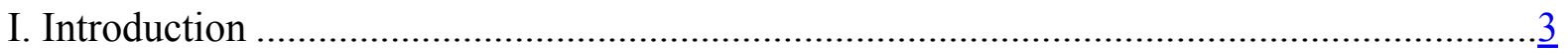

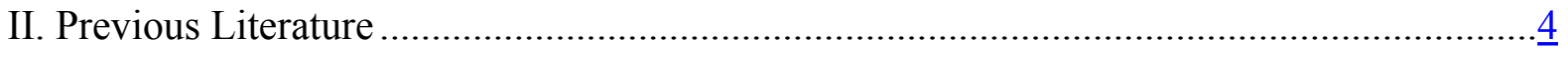

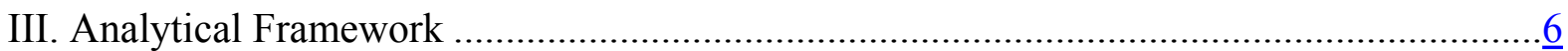

A. Fiscal Policy and Sovereign Spreads -A Conceptual Framework........................... $\underline{6}$

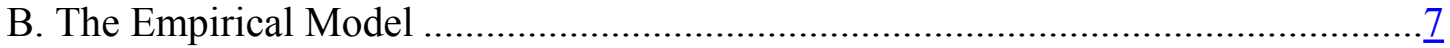

C. Data, Estimation, and Results …..........................................................

IV. Conclusions and Policy Implications...............................................................

Tables

1. List of Countries and Number of Annual Observations …....................................

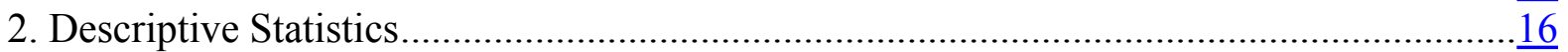

3. Regression Results —-Baseline .............................................................................. $\frac{17}{18}$

4. Fixed Effects Estimates_Effects of Fiscal Policy on Spreads ......................................18

5. Arellano-Bond Estimates_Effects of Fiscal Policy on Spreads .....................................19

6. Correlation Matrix Deviations from Country Means...................................................20

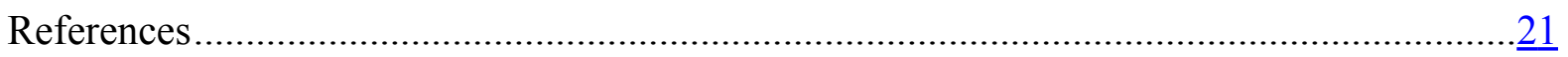




\section{INTRODUCTION}

How do financial markets react to fiscal policy decisions of sovereign borrowers? Relatively few studies have focused on the effects of fiscal policies on sovereign bond spreads. ${ }^{2}$ To empirically examine the effect of fiscal policies, it is important to have the right measurement for these policies. Most empirical studies have included some measure of the fiscal deficit in the macroeconomic fundamentals affecting spreads. However, the fiscal deficit can be a misleading indicator. For example, if the fiscal deficit increases because of public investment activities that promise high returns in the future, short-run spreads may decrease. Alternatively, if the fiscal deficit increases because of higher wage expenditures, spreads may increase.

This paper contributes to the existing literature in two ways. First, it introduces fiscal policy into an empirical model of spreads. This allows us to analyze the effects of changes in public expenditure and revenue on spreads, and to ascertain how tax-financed and debt-financed increases in public expenditure influence sovereign risk. Second, we investigate how the composition of the fiscal adjustment is priced in sovereign bonds. Following Alesina and Perotti (1996), we consider two types of fiscal adjustments, based on their composition: Type I, which is largely expenditure-based, with the brunt of the adjustment falling on current expenditures; and Type II, which mostly relies on tax increases and drastic cuts in public investment.

We find that Type I adjustments significantly lower spreads, while Type II adjustments have no statistically significant impact on the pricing of sovereign issues. This suggests that what matters for the financial market is not a reduction in fiscal deficits per se, but how the adjustment is brought about. Our regression results confirm the country case study results of Alesina and Perotti (1996), who show that Type I fiscal adjustments lead to a more permanent consolidation of the budget. We also find that debt-financed current spending increases sovereign risk by more than tax-financed current spending, suggesting that international investors have some preference for the latter. The results also suggest that, ceteris paribus, (i) on average, higher revenues have no statistically significant effect on spreads; (ii) higher current expenditure increases country spreads, while capital expenditure has no statistically significant effect on spreads. In line with previous studies, we find strong evidence that macroeconomic fundamentals (as measured by annual inflation), the country's liquidity position (as measured by total reserve in percent of GDP), and the country's solvency (as measured by total debt in percent of gross national income) are important determinants of spreads.

The rest of the paper is organized as follows. Section II briefly reviews previous literature on sovereign risk pricing. Section III discusses the analytical framework and analyzes the data

\footnotetext{
${ }^{2}$ A rare example is António and Strauch (2004), who investigate the impact of fiscal policy events on the interest rate swap spreads of long-term bonds, using events study methodology. They find that fiscal events can have an impact on swap spreads of up to five basis points.
} 
set and empirical results. Section IV highlights the main conclusions and their policy implications.

\section{Previous Literature}

The empirical literature of the macroeconomic determinants of spreads has often sought to identify specific country characteristics affecting spreads. This line of analysis can arguably be traced to Edwards (1984) who looked at 700 loans extended to 19 developing countries from 1976 to 1980, and showed that debt has a statistically significant positive effect on spreads and foreign currency reserves have a statistically negative effect on spreads. A number of authors have confirmed these results using different sets of countries and periods, and provided a strong basis to presume that liquidity indicators, solvency indicators, and macroeconomic fundamentals are important determinants of sovereign spreads on both primary and secondary issues. For instance, Cline and Barnes (1997), using annual data for 1992-96 conclude that debt, reserves, and inflation have the anticipated effects on emerging market lending spreads on Eurobonds. Min (1998) obtains similar results for emerging market bond spreads during 1991-95, the years before the Asian crisis. More recent studies, such as Catão and Kapur (2004) and Catão and Sutton (2001), argue that both macroeconomic volatility and the levels of macroeconomic variables are significant determinant of spreads, as they induce higher default risk.

Another important factor behind the pricing of sovereign bonds relates to credit ratings. Sobrinho (2004) notes that the credit rating is an overall indicator of the debtor's ability and willingness to service its debts, which makes it attractive to study its determinants. In a pioneering study, Cantor and Packer (1996) investigate the determinants of credit ratings and their link with sovereign spreads, using cross-sectional data for 49 countries. Their results show that credit ratings are mostly explained by a set of six macroeconomic variables: per capita income, GDP growth, inflation, external debt, level of economic development, and default history. They further conclude that credit ratings independently affect sovereign spreads. A recent study by Kaminsky and Schmukler (2001) estimates that a one rate downgrade leads to a 3 percent increase in average sovereign spreads.

Some authors also highlight the role of monetary and exchange rate regimes in determining spreads. Uribe (2002) argues that different monetary policy specifications affect the equilibrium behavior of default and sovereign risk premium. He finds that in an economy where the central bank pegs the price level, both the default and the risk premium can be highly persistent. A recent study by Jahjah and Yue (2004) investigates empirically the influence of exchange rate policy on sovereign bond spreads. They show that an overvalued real exchange rate significantly increases sovereign spreads, with the size of this effect being higher under a fixed-exchange rate. However, during crisis periods, this result is reversed, with a free floating regime leading to higher borrowing cost.

Some authors emphasize the role of political business cycle and corruption in explaining the pricing of sovereign debt. For example, Block and Vaaler (2004) argue that both rating agencies and investors view elections negatively, thereby imposing additional credit cost. 
They show that elections are associated with a higher frequency of sovereign rating downgrades, while pre-election bond spreads are systematically higher than post-election ones. Similarly, Ciocchini, Durbin, and Ng (2002) contend that corruption increases emerging market bond spreads. Using "perceived corruption" data by Transparency International and controlling for macroeconomic effects, they show that more corruption translates into a higher risk premium. However, they find no strong evidence that sensitivity to corruption increased in the aftermath of Asian crisis.

Other studies stress the role of moral hazard in explaining changes in spreads. Zhang (1999) examines the longer-term impact of the Mexico bailout in 1995 and finds that a post-Mexico dummy is positive but insignificant, surely suggesting an absence of moral hazard. Similarly, Lane and Phillips (2000) investigate the reactions of bond spreads to three categories of events: (i) announcement of new IMF-supported programs in countries undergoing financial crises; (ii) news about Fund's financial resources or commitments to individual members; and (iii) news regarding the Russia program in 1998. In most cases, they also fail to uncover any significant reaction of spreads to these events. However, Dell'Ariccia, Schnabel, and Zettelmeyer (2002) argue that these negative results are due to the deficiencies in the methodologies used. In studying the 1998 Russian crisis, they find that the nonbailout by the IMF of this crisis has made spreads more sensitive to country fundamentals and led to increases in the level and variance of spreads. These findings are interpreted as supporting the presence of IMF-related moral hazard.

A number of authors focus on the determinants of debt crisis, in view of the strong correlation between default episodes and higher spreads. Kaminsky, Lizondo, and Reinhart, (1997) argue that variables providing early warning signals of banking and currency crisis may play a key role in explaining changes in spreads. They suggest that variables providing early warning signals may include deviations of the real exchange rate from trend, equity prices, and the ratio of broad money to gross international reserves. Using a sample of 59 countries, Reinhart (2002) finds that debt crises tend to be preceded by currency crises. Detragiache and Spilimbergo (2001) analyzing the role of liquidity indicators on default, show that, for a given total external debt, the probability of crisis increases with the proportion of short-term debt and debt service coming due. In the same vein, Manasse, Roubini, and Schimmelpfennig (2003) develop an early warning model of sovereign debt crises, which identifies solvency and liquidity factors that predict a debt crisis episode one year in advance. The key factors include high levels of foreign debt relative to GDP, short-term debt relative to foreign reserves, and debt service indicators.

The literature also points to the role of external factors-including world interest rate, terms of trade shocks - in the sovereign pricing. The empirical evidence on the impact of international interest rates on sovereign spreads is mixed. For example, Arora and Cerisola (2001) suggest that, like country specific fundamentals, the stance and predictability of U.S. monetary policy are equally important in determining country risk. They also show that the level of U.S. interest rates has direct positive effects on sovereign bond spreads in several developing countries in Latin America, Asia, and Eastern Europe. In contrast, Eichengreen and Mody (1998a and 1998b) argue that U.S. interest rates in the 1990s are negatively 
associated with spreads for Latin American and East Asian countries. The authors explain this surprising finding by the negative effect of a rise in U.S. rates on bond supply by emerging-country issuers, which increases bond prices and as result lowers sovereign spreads.

Increased financial globalization has also heightened the role of market sentiment and contagion in sovereign pricing. Many have argued that "irrational investor behavior" or "herd mentality" often drive changes in sovereign spreads, largely because of high costs of acquiring and processing information. ${ }^{3}$ In particular, using data on nearly 1,000 developing country bonds issued during 1991-96, Eichengreen and Mody (1998b) find that changes in spreads are mostly explained by market sentiment rather than macroeconomic fundamentals. Similarly, Kaminsky and Schmukler (1999) show that changes in a given country's creditworthiness can affect the stock and bond markets of other countries. In the same vein, and following the Mexican crisis of 1994, Calvo and Reinhart (1996) document high correlation between sovereign spreads for Asian and Latin American emerging countries. Accordingly, Kaminsky and Schmukler (2001) argue that rating-induced changes among emerging markets trigger changes in sovereign spreads in foreign countries. Using data for 15 emerging countries over 1997-2003, McGuire and Schrijvers (2003) take this analysis further by showing that about one third of each country's average total daily changes in spreads is caused by common factors. Mauro, Sussman, and Yafeh (2002) also find that global events were the main driving forces behind changes in spreads in the 1990s, while country-specific events mostly explained change in spreads in 1870-1913.

\section{ANAL YTICAL FRAMEWORK}

\section{A. Fiscal Policy and Sovereign Spreads-A Conceptual Framework}

To undertake fiscal adjustment, governments can increase revenue (through increasing tax rates and/or broadening tax bases) and/or cut expenditure. Fiscal adjustment can affect sovereign risk through three main channels: (i) macroeconomic effects; (ii) expectation effects; and (iii) creditability effects. A key question is what drives the size of these effects. In an influential paper, Alesina and Perotti (1996) contend that the driving force is the composition, rather than the size, of the fiscal adjustment. They propose a conceptual framework centered on two findings.

- $\quad$ Reductions in government spending may have a longer lasting effect on the fiscal deficit than tax increases. A large spending cut, which signals a permanent change in fiscal policy, raises the expectation of lower future taxes, there by increasing the wealth of consumers. The wealth effects on consumption will in turn lead to economic expansion that helps reduce further the fiscal deficit through increased tax revenues.

\footnotetext{
${ }^{3}$ See, for example, Calvo and Mendoza, 2000, and Eichengreen and Mody, 1998b.
} 
- The composition of government spending cuts is important to the sustainability of fiscal adjustment. For example, reducing wages and welfare programs through structural reforms are likely to have lasting effects, and hence reveal the government's strong commitment to fiscal adjustment.

Based on these findings, Alesina and Perotti (1996) define two types of fiscal adjustments:

- $\quad$ Successful fiscal adjustment ${ }^{4}$ (Type I) relies primarily on expenditure cuts and, in particular, on cuts in transfers to households, social security, and government wages and employment, and not on tax increases, in particular, on no tax increases on households.

- Unsuccessful fiscal adjustment (Type II) relies on tax increases on the revenue side and cuts in public investment on the expenditure side.

This conceptual framework provides the basis for our empirical analysis of the effects of fiscal policy on spreads. One would expect that successful fiscal adjustments are likely to enhance expectation and credibility effects, thereby reducing sovereign risk.

\section{B. The Empirical Model}

The theoretical model that underpins the empirical model follows Edwards $(1985,1986)$. Let us assume a risk-neutral investor lending to a given country that is a price-taker in the world capital market. The equilibrium condition for the optimal allocation of the investor's portfolio can be expressed as

$$
\left(1+r^{*}\right)=p d \cdot \omega_{0}+(1-p d)\left(1+r^{L}\right)
$$

Where $r^{*}$ is the risk-free world interest rate; $p d$ is the probability of default; $\omega_{0}$ is the payment made by the borrower to the lender in the default state; and $r^{L}$ is the lending rate.

It is straightforward to derive from equation (1) the equilibrium condition for the spread:

$$
s=\frac{p d}{1-p d}\left(1+r^{*}-\omega_{0}\right)
$$

Where $s$ is the spread over the risk-free world interest rate $\left(r^{*}\right)$

It is standard practice to specify a logistic form for the probability of default as follows:

\footnotetext{
${ }^{4}$ Alesina and Perotti, 1996, define "success" as a long lasting fiscal consolidation. They also find that successful adjustments have expansionary effects on consumption and output.
} 


$$
p d=\frac{\exp \left(\sum_{k=1}^{n} \beta_{k} Z_{k}\right)}{1+\exp \left(\sum_{k=1}^{n} \beta_{k} Z_{k}\right)}
$$

Where the $Z_{k}$ are determinants of the probability of default that are elaborated below, and the $\beta_{\mathrm{k}}$ are the corresponding coefficients. By combining equations (2) and (3), and taking the natural logarithm, the resulting equation can be written as

$$
\log s=\log \left(1+r^{*}\right)+\sum_{k=1}^{n} \beta_{k} Z_{k}
$$

By adding the country and time dimensions and allowing for the time and fixed effects, the stochastic model to be estimated is given by

$$
\log _{i t}=\alpha_{i}+\beta Z_{i t}+\lambda_{t}+\eta_{i t}
$$

where $s_{i t}$ is the secondary market spread over the risk-free world interest rate in country $i$ in year t, $\alpha_{i}$ is a country fixed effect, $\lambda_{t}$ is the time fixed effect, and $\eta_{i t}$ is a Gaussian error term. In this framework $\mathrm{r}^{*}$ is absorbed in the time fixed effect $\lambda_{t}$.

With regard to the explanatory variables, previous studies point to a very large number of variables as possible determinants of sovereign risk. We aim for a parsimonious empirical model, while capturing the key indicators of creditworthiness. We, therefore, include the main indicators of liquidity, solvency, and macroeconomic fundamentals, as control variables, to isolate the fiscal policy impact on spreads. ${ }^{5} \mathrm{We}$ also consider default history and contagion indicators. Given that our main objective is to focus on the impact on spreads of fiscal policy, we disaggregate the fiscal balance into revenue and spending components (capital and current expenditure).

\footnotetext{
${ }^{5}$ Countries may react to increasing spreads by adjusting their fiscal policy. Our estimates do not suffer from reverse causality if countries react in time period $t+1$ or thereafter to changes in spreads in time period $t$, because fiscal policy and spreads enter our model contemporaneously.
} 
Specifically, the following variables are considered determinants of the probability of default and included in the $Z_{\text {it }}$ vector:

- $\quad$ Ratio of total debt outstanding to Gross National Income. ${ }^{6}$ Key indicator of a country's long-run solvency, this variable is expected to be positively associated with the spread. A higher debt-to-GNI increases the default probability, and hence the sovereign risk.

- $\quad$ Total foreign exchange reserves as a percentage of GDP. It is a stock-based measure of a country's capacity to service its external debt. It will be negatively related to the sovereign spread.

- Inflation rate. Inflation is a key indicator of macroeconomic stability. Monetization of fiscal deficits can lead to high inflation rates, which reduces growth by raising the cost of acquiring capital. It has also been shown that a higher degree of political instability is associated with higher inflation (e.g., Aisen and Veiga, 2005). For all these reasons, higher inflation will tend to increase sovereign risk.

- Default history. Defaults increase sovereign risk. Therefore, this variable is expected to have a negative coefficient. The variable measuring whether a country is in default is based on the classification by Manasse and Roubini (2005, page 9, Table 1), and Gelos, Sahay, and Sandleris (2004, page 36, Table A7). The indicator variable is set to 1 if the country in a specific year is classified by either of the paper to be in a default period.

- $\quad$ Regional spread index. ${ }^{7}$ This variable measures regional contagion. The reason why we use a regional index is that many authors have suggested that contagion is a more regional than global phenomenon (see, for example, Kaminsky and Reinhart, 2000). We group the sample countries into four regions, Europe, Latin America, Africa, and Asia. We expect the contagion variable to have a positive coefficient.

- $\quad$ Total revenue-to-GDP. Higher revenue leads to improved primary balance, everything else being equal. This implies a positive sign for its coefficient.

- Government current spending-to-GDP ratio. Higher current spending adds to the deficit often without improving growth prospects. It is expected to have a positive sign.

\footnotetext{
${ }^{6}$ We use Gross National Income instead of GDP because the former, which captures the net factor income and current transfers, is a better measure of the ability of a country to pay, and therefore, it is often considered a more appropriate measure of a country's solvency.

${ }^{7}$ By construction, we exclude from the index the country, of which spread is being explained.
} 
- $\quad$ Public investment-to-GDP ratio. Edwards, 1985, contends that its coefficient will be negative, because higher investment improves growth prospects. However, as indicated in Edwards (1986), some authors argue that higher investment ratios may increase the default risk, to the extent that investment undertaken tends to reduce the penalty cost in case of default. Therefore, the sign of the coefficient is ambiguous.

\section{Data, Estimation, and Results}

\section{Data}

The data set for the dependent variable is the stripped spread obtained from the Emerging Markets Bond Index Global (EMBI Global). The EMBI Global, which is widely used, tracks total returns for traded external debt instrument in emerging markets issued by sovereign and quasi-sovereign entities. These instruments include U.S. dollar-denominated Brady bonds, loans, and Eurobonds. Bonds included in the index must have a face value of over US $\$ 500$ million (with maturity of more than $2 \frac{1}{2}$ years) and verifiable daily prices and cash flows. The EMBI Global which currently covers 32 countries, is a market-capitalization weighted index, with the country's spread computed as the weighted average of the spreads of the included bonds. ${ }^{8}$ The bond spread is measured against a comparable U.S. government bond. The data sources of our right-hand side variable are the IMF's WEO database and IFS.

Table 1 shows the country coverage and the number of annual observations. We use all country-year observations that are available from the EMBI Global between 1994 and 2003, and for which our covariates are available. Table 2 contains the list of variables and summarizes the descriptive statistics of the data, and Table 6 provides a correlation matrix of the variables employed in the analysis.

\section{Results}

Table 3 presents baseline results where the model is estimated with and without country fixed effects. The specification without country fixed effects allows us to compare our results to previous studies. The pooled OLS point estimates and the robust standard errors in columns 1 and 2 of Table 3 are roughly similar to the country fixed effects estimates in Table 3 , columns 3 and 4. Debt, reserves, inflation, and default history have the expected effect on spreads and the point estimates are statistically significant. The estimate on the contagion variable is not statistically significant. The magnitude and sign of the of estimates in Table 3 are roughly consistent with the findings in the previous literature (see, for example, Edwards, 1986, and Min, 1998). The results on debt in Table 3, column 4 imply that a 1 percentage point increase in debt to GDP leads to about 1.3 percent increase in spreads. The country and year fixed effects model explains about 67 percent of the variation in sovereign spreads.

\footnotetext{
${ }^{8}$ An alternative data source for spreads is the EMBI+ index, which covers 19 countries. We chose the EMBI Global because it covers more countries and has more observations than the EMBI+.
} 
Table 4 summarizes the panel regression results that include fiscal policy variables. ${ }^{9}$ As before, all regressions are estimated with robust standard errors. Inclusion of the fiscal policy variables does not change the point estimates on debt, reserves, inflation, and default history by a large amount. However, the contagion variable becomes significant at the 5 percent level, suggesting that regional contagion may affect the country's sovereign risk evaluation, without any change in the macro fundamentals.

The point estimates for the total-debt to GNI ratio remain positive and consistently significant at the 1 percent level across specifications, implying that countries with higher debt are penalized in international capital markets. The results show that a 1 percentage point increase in the debt-to-GNI ratio may cause the spread to widen by a range of

1.1-1.2 percent, depending on the specification. This estimated impact is broadly in line with previous studies (for example, Min, 1998). Similarly, the coefficient of the liquidity indicator (total foreign exchange reserves in percent of GDP) is also consistently significant at 1 percent level, with a negative sign as expected. Like in Edwards (1984), we find that financial markets are sensitive to changes in reserves, showing evidence for the importance of liquidity concerns in the international investor's decision. With regard to macroeconomic fundamentals, the results show that the effect of higher inflation on spreads is statistically significant and positive as expected. Default history variable remains statistically significant.

The results in Table 4 show that current expenditure cuts would be expected to affect spreads more than revenue increases do. In all three specifications, current spending has a negative and statistically significant effect on spreads, and the coefficient estimate is broadly similar across all specifications. A 1 percentage point reduction in current spending reduces spreads between 2.7 percent and 2.9 percent, while a revenue-based fiscal improvement of the same size has no statistically significant effect on spreads. In the more complete specifications (columns 2 and 3), the point estimate on revenues is negative, but not statistically significant. If anything, it appears that investors prefer increases in taxes that generate revenues, rather than increases in debt, to finance spending. These findings support the Alesina and Perotti (1996) hypothesis that a reduction in current expenditure has a larger effect than increases in revenue. The coefficient of government investment is not found to be statistically significant. The size of public investment, as opposed to its quality, may not matter to investors.

The regression results allow drawing conclusions on whether financial markets prefer expenditures financed from debt or expenditures financed out of revenues. If a country finances current spending by raising revenue, the increase in revenue would not have an independent significant effect on the spread, in addition to the impact of increasing current spending; whereas, in the case of the debt-financed current spending, the increase in the country's indebtedness will further heighten the country risk. Put differently, taxes-financed

\footnotetext{
${ }^{9}$ Alesina and others, 1999, also use a similar regression analysis to study the effects of fiscal adjustments on private investment. They found that cuts in public spending (in particular, government wage bill) substantially increase investment, while increases in taxes reduce investment.
} 
current spending is not equivalent to debt-financed current spending, as far as the impact on spreads is concerned. For example, based on the specification 3 in Table 4, a 1 percentage point increase in current spending raises spreads by about 4 percent ${ }^{10}$ if financed by debt, and by about 2.9 percent $^{11}$ if financed by taxes. These findings suggest that financial markets prefer revenue-financed spending as opposed to debt-financed spending.

These various results indicate that the market values a reduction in current spending-largely dominated by transfers, social security, and wages - more than investment cuts, perhaps under the perception that the latter could have a more immediate adverse impact on growth. As a result, the overall evidence supports the notion that Type I fiscal adjustments have more impact on sovereign spreads than the Type II adjustments, although these two adjustment scenarios have the same size in the first year of the implementation. As pointed out by Alesina and Perotti (1996), the reason is that Type I fiscal adjustment often has expansionary effects on output and appears more credible by raising the expectation of a permanent reduction in fiscal deficits, and hence a lower debt-to-GDP ratio.

Once concern regarding the estimates is that fiscal policy and some of the other covariates may be endogenous due to reverse causality or an omitted variable bias. Reverse causality issues arise when governments change their fiscal policy in response to changes in spreads. Omitted variable biases arise when unobserved shocks affect both spreads and policy variables on the right hand side. Finally, current spending includes interest payments. Although spreads measure the price of bonds and while increasing spreads do not imply that a country's payment on bonds increase, changes in spreads may lead to changes in interest payments on bonds issued in the future.

To take into account the short-term dynamics in spreads and to address endogeneity concerns, we use the Arellano-Bond dynamic panel estimator (A-B estimator), ${ }^{12}$ proposed by Arellano and Bond (1991). A-B estimator is a Generalized Method of Moments (GMM) procedure for looking at efficient Instrumental Variable estimator (IV estimator) for dynamic panel data models. The key insight behind A-B estimator is that, in a dynamic panel data setting, additional instruments can be derived from the orthogonality conditions that exist between the lagged dependent variable and the error terms. Table 5 reports the results of this estimator. Since this is a first-difference estimator with lagged variables as instruments, we lose about one third of the observations, and results have to be interpreted with caution. The results yield interesting patterns. The coefficient on the lagged dependent variable is positive and significant at the 1 percent level in all the three specifications. With the exception of the

\footnotetext{
${ }^{10}$ This number is obtained by adding the values of the coefficients estimates of debt to GNI and current expenditure to GDP.

${ }^{11}$ As the coefficient estimate of government revenue is not significant, it has not been added to the coefficient estimate of current expenditure to GDP. Adding both coefficients does not change the conclusion.

${ }^{12}$ The computer program used is xtabond2 developed by Roodman, 2005.
} 
default history variable, all the variables that were significant in the fixed effects regression reported in Table 4 remain significant, although with smaller coefficients. The inclusion of the lagged dependent variable as an explanatory variable already incorporates the information content of the default history. This reduces the explanatory power of the latter. Spreads increase between 1.4 percent and 1.8 percent for a one-percentage-point increase in government expenditure. The point estimate on government revenues remains statistically insignificant. The Arellano-Bond estimates also provide support that financial markets penalize current spending increases, while increases in public investment have no effect on spreads.

\section{Sensitivity and robustness}

We have checked the sensitivity and the robustness of the results with respect to alternative specifications, and concluded that our findings are robust to a variety of different specifications. First, we estimated the model with alternative measures of solvency, liquidity, and the results obtained were very similar to those reported. In particular, total debt-export ratio, reserve-to-import ratio, the share of short-term debt to total debt were found to be significant with the right sign.

Second, we also test whether government elections and currency crises are important in explaining the changes in spreads. We defined a currency crises as an event where a devaluation of 25 percent or more occurred and inflation was above 10 percent. These criteria identified Argentina (2002), Brazil (1999), Mexico (1995), Venezuela (2002), Malaysia (1998), Philippines (1998), Nigeria (1999), Russia (1998), and Ukraine (1998, 1999). The election variable is a dummy variable equaling one in the year of the election. We have election dummy variables for presidential and parliamentary election. The inclusion of the election dummy variable was motivated by findings that elections affect fiscal policy, and thus elections may also have a direct effect on spreads. In all specifications, these election variables and our measure of currency crises variables are found not to be significant. The point estimates on the election variables were statistically insignificant, regardless as to whether just presidential elections were included in the regressions, or both presidential and parliamentary elections.

Third, for the dynamic specification, we check that the ranking of the OLS, IV, and within-groups parameter estimates are in line with the theory, and that our consistent IV estimator is not subject to any serious finite sample bias. The theory suggests that the OLS estimate of the dynamic model would be biased upward, while the within group estimate is likely to be biased downward (see Bond, 2002). As a result, if the IV estimator is not subject to a serious bias, it should lie between these two estimators. With the limited number of observations, a potential source of finite sample bias is the use of too many lagged instruments. As suggested by Bond (2002), we check the sensitivity of our results to using more or fewer lagged variables, and choose the number of lags (three) that gives a coefficient estimate of the lagged dependent variable, which is well below the OLS estimate and above the within group estimate. 
Finally, we conduct a number of specification and diagnostic tests on the dynamic model (Table 5). Hansen's test of over-identification suggests that the instruments used, as a group, appear exogenous. Moreover, the Arellano-Bond test for AR(1) and AR(2) reported in Table 5 suggest that the pattern of serial correlation in the first-differenced residuals shows significant negative first-order serial correlation, but no significant second-order serial correlation, which is consistent with the assumption that the disturbances in the level dynamic equation are serially uncorrelated.

\section{Conclusions ANd Policy IMPlications}

This paper contributes to the empirical literature on the determinants of spreads by introducing fiscal policy in an empirical model of sovereign spreads. Using panel data from emerging market countries, we examine whether the composition of fiscal adjustment matters for the pricing of sovereign risk. We find that reductions in expenditure have larger effects on spreads than increases in revenue. Moreover, current spending cuts lower sovereign spreads by more than compressions in public investment. We show that international investors have a small preference for tax-financed spending over debt-financed spending.

Overall, current expenditure-based fiscal adjustments reduce sovereign spreads more than revenue-based ones. This confirms Alesina and Perotti's (1996) findings that the most successful fiscal adjustments rely primarily on current spending cuts. In line with the empirical literature on the determinants of spreads, we also find that liquidity and solvency indicators, as well as macroeconomic fundamentals, are important determinants of sovereign spreads.

This study suggests a number of policy implications for countries seeking to lower their borrowing cost on international capital markets. First, a country is better off pursuing current expenditure-based fiscal adjustments when fiscal adjustment is needed to reassure financial markets. Second, given the importance capital markets attach to a reserves-to-GDP ratio, a government can aim at increasing its foreign reserves position through appropriate macroeconomic and structural policies. Third, since financial markets view high debt ratios negatively, sound fiscal policy and prudent debt management are needed to lower the debt-to-GDP ratio.

In future research, a number of open questions should be addressed. First, government revenue and expenditure should be disaggregated further. For instance, government revenue could be broken down into taxes on households, taxes on business, indirect taxes, and social security contributions. Similarly, current spending could be further disaggregated into different types of transfers, wages, and nonwage consumption. Second, it would be useful to deepen the empirical analysis by introducing the country's own history of failed or successful fiscal adjustments. Finally, there are reasons to believe that the financial markets treatment of spending and revenue decisions would be influenced by the initial conditions of fiscal and debt variables. Data that have a larger number of countries with a longer time series than those used in this paper, would make these inquiries promising. 
Table 1. List of Countries and Number of Annual Observations

\begin{tabular}{|c|c|c|c|}
\hline Country Num & $\begin{array}{l}\text { ber of Annual } \\
\text { Observations }\end{array}$ & Country Num & $\begin{array}{l}\text { ber of Annual } \\
\text { Observations }\end{array}$ \\
\hline Algeria 5 & & Pakistan & 3 \\
\hline Argentina & 11 Panam & $\mathrm{a}$ & 8 \\
\hline Brazil & 10 Per & $\mathrm{u}$ & 7 \\
\hline Bulgaria & $10 \mathrm{Phi}$ & lippines & 6 \\
\hline Chile & $5 \mathrm{Pol}$ & and & 10 \\
\hline China & $3 \mathrm{R}$ & ussia & 6 \\
\hline Columbia & 7 So & uth Africa & 9 \\
\hline Côte d'Ivoire & 6 Thai & land & 7 \\
\hline Croatia & $8 \mathrm{Tu}$ & nisia & 2 \\
\hline Dominican Republic & 3 Tur & key & 8 \\
\hline El Salvador & $2 \mathrm{Uk}$ & raine & 4 \\
\hline Ecuador & $9 \mathrm{Ur}$ & uguay & 3 \\
\hline Egypt & 3 Venez & uela & 11 \\
\hline Hungary & 5 & & \\
\hline Malaysia & 8 & & \\
\hline Mexico & 11 & & \\
\hline Morocco & 6 & & \\
\hline Nigeria & 9 & & \\
\hline Total Observations & & & 185 \\
\hline
\end{tabular}


Table 2. Descriptive Statistics

\begin{tabular}{|c|c|c|c|c|c|}
\hline Variable & & Mean & $\begin{array}{l}\text { Standard } \\
\text { Deviation }\end{array}$ & Min & Max \\
\hline Lnbsprd_mm & $\begin{array}{l}\text { Log of average annual } \\
\text { bond spread }\end{array}$ & 6.294 .8 & 30 & 4.050 & 8664 \\
\hline Debt to GNI & $\begin{array}{l}\text { Total debt outstanding } \\
\text { as fraction of GNI }\end{array}$ & .574 .2 & 62 & .135 & 1.570 \\
\hline $\begin{array}{l}\text { Reserves to } \\
\text { GDP }\end{array}$ & $\begin{array}{l}\text { Total reserves as } \\
\text { fraction of GDP }\end{array}$ & .128 .0 & 75 & .010 & .375 \\
\hline Log inflation & Log of annual inflation & 2.3641 & 160 & 0 & 7.99 \\
\hline Indefault & $\begin{array}{l}\text { Dummy of being in } \\
\text { default }\end{array}$ & .238 .4 & 26 & 0 & 1 \\
\hline Regionexself & $\begin{array}{l}\text { Regional spread index, } \\
\text { excluding the country }\end{array}$ & 678.3435 & 2.10 & 69.52 & 2215.585 \\
\hline $\begin{array}{l}\text { Gov. Revenue } \\
\text { to GDP }\end{array}$ & $\begin{array}{l}\text { Total government } \\
\text { revenue as a fraction of } \\
\text { GDP }\end{array}$ & .267 .0 & 80 & .149 & .511 \\
\hline $\begin{array}{l}\text { Pub. Inv. to } \\
\text { GDP. }\end{array}$ & $\begin{array}{l}\text { Public investment as a } \\
\text { fraction of GDP }\end{array}$ & 0.511 .0 & 35 & .007 & .207 \\
\hline $\begin{array}{l}\text { Current Exp. To } \\
\text { GDP }\end{array}$ & $\begin{array}{l}\text { Current expenditure as } \\
\text { a fraction of GDP }\end{array}$ & .248 .0 & 98 & .004 & .490 \\
\hline
\end{tabular}

$\mathrm{N}=185$. 
Table 3. Regression Results-Baseline

(Dependent Variable: Annual Mean Spread)

\begin{tabular}{|c|c|c|c|c|}
\hline Variable & $\begin{array}{c}1 \\
\text { OLS, Year } \\
\text { Fixed Effects }\end{array}$ & $\begin{array}{c}2 \\
\text { OLS, Year } \\
\text { Fixed Effects }\end{array}$ & $\begin{array}{c}3 \\
\text { OLS, Country and } \\
\text { Year Fixed Effects }\end{array}$ & $\begin{array}{c}4 \\
\text { OLS, Country and } \\
\text { Year Fixed Effects }\end{array}$ \\
\hline Debt to GNI & $\begin{array}{l}1.594^{* * *} \\
(0.149)\end{array}$ & $\begin{array}{l}1.596^{* * *} \\
(0.149)\end{array}$ & $\begin{array}{l}1.253^{* * *} \\
(0.258)\end{array}$ & $\begin{array}{c}1.288 * * * \\
(0.246)\end{array}$ \\
\hline Reserves to GDP & $\begin{array}{l}-4.589 * * * \\
(0.565)\end{array}$ & $\begin{array}{l}-4.575^{* * *} \\
(0.579)\end{array}$ & $\begin{array}{l}-3.806^{* * *} \\
(1.112)\end{array}$ & $\begin{array}{c}-3.745^{* * *} \\
(1.105)\end{array}$ \\
\hline Log inflation & $\begin{array}{l}0.162^{* * *} \\
(0.378)\end{array}$ & $\begin{array}{l}0.162 * * * \\
(0.038)\end{array}$ & $\begin{array}{l}0.123^{* * *} \\
(0.044)\end{array}$ & $\begin{array}{c}0.128^{* * *} \\
(0.045)\end{array}$ \\
\hline Indefault 0 . & $\begin{array}{l}390^{* * * *} \\
(0.084)\end{array}$ & $\begin{array}{c}0.390^{* * *} \\
(0.0845)\end{array}$ & $\begin{array}{l}0.292^{* * * *} \\
(0.082)\end{array}$ & $\begin{array}{c}0.282 * * * \\
(0.079)\end{array}$ \\
\hline Regionexself & & $\begin{array}{l}9.48 \mathrm{E}-06 \\
(1.08 \mathrm{E}-04)\end{array}$ & 1. & $\begin{array}{c}83 \mathrm{E}-04 \\
(1.21 \mathrm{E}-04)\end{array}$ \\
\hline R-squared 0. & 68 & 0.69 & 0.66 & 0.67 \\
\hline
\end{tabular}

$\mathrm{N}=143$. Robust standard errors in parentheses. Column 1 includes year effects. Applying a two-tailed test, *indicates statistical significance at the 10 percent level, ${ }^{* *}$ at the 5 percent level, and ${ }^{* * *}$ at the 1 percent level. 
Table 4. Fixed Effects Estimates—Effects of Fiscal Policy on Spreads (Dependent Variable: Annual Mean Spread)

\begin{tabular}{|c|c|c|c|}
\hline Variable & 1 & 2 & 3 \\
\hline Debt to GNI & $\begin{array}{c}1.216 * * * \\
(0.270)\end{array}$ & $\begin{array}{c}1.067 * * * \\
(0.279)\end{array}$ & $\begin{array}{c}1.083 * * * \\
(0.271)\end{array}$ \\
\hline Reserves to GDP & $\begin{array}{c}-3.380 * * * \\
(1.132)\end{array}$ & $\begin{array}{c}-3.824 * * * \\
(1.110)\end{array}$ & $\begin{array}{c}-3.600 * * * \\
(1.095)\end{array}$ \\
\hline Log inflation & $\begin{array}{c}0.176 * * * \\
(0.410)\end{array}$ & $\begin{array}{c}0.145^{* * *} \\
(0.039)\end{array}$ & $\begin{array}{c}0.151 * * * \\
(0.038)\end{array}$ \\
\hline Indefault & & $\begin{array}{c}0.258 * * * \\
(0.084)\end{array}$ & $\begin{array}{c}0.253 * * * \\
(0.081)\end{array}$ \\
\hline Regionexself & & & $\begin{array}{c}2.24 \mathrm{E}-04^{* *} \\
(1.13 \mathrm{E}-04)\end{array}$ \\
\hline Government revenue to GDP & $\begin{array}{c}0.713 \\
(1.143)\end{array}$ & $\begin{array}{c}-0.298 \\
(1.248)\end{array}$ & $\begin{array}{c}-0.254 \\
(1.239)\end{array}$ \\
\hline Public investment to GDP & $\begin{array}{c}0.413 \\
(3.443)\end{array}$ & $\begin{array}{c}0.206 \\
(3.329)\end{array}$ & $\begin{array}{l}-1.694 \\
(3.423)\end{array}$ \\
\hline Current expenditure to GDP & $\begin{array}{c}2.690 * * * \\
(0.926)\end{array}$ & $\begin{array}{c}2.841 * * * \\
(0.891)\end{array}$ & $\begin{array}{c}2.938 * * * \\
(0.882)\end{array}$ \\
\hline R-squared & 0.67 & 0.69 & 0.70 \\
\hline
\end{tabular}

$\mathrm{N}=185$. Robust standard errors in parentheses. All columns include year and country fixed effects. Applying a two-tailed test, ${ }^{*}$ indicates statistical significance at the 10 percent level, ${ }^{* *}$ at the 5 percent level, and $* * *$ at the 1 percent level. 
Table 5. Arellano-Bond Estimates_Effects of Fiscal Policy on Spreads

(Dependent Variable: Annual Mean Spread)

\begin{tabular}{|c|c|c|c|}
\hline Variable & 1 & 2 & 3 \\
\hline Lagged dependent variable & $\begin{array}{c}0.435^{* * *} \\
(0.088)\end{array}$ & $\begin{array}{c}0.423 * * * \\
(0.017)\end{array}$ & $\begin{array}{l}0.431 * * * \\
(0.084)\end{array}$ \\
\hline Debt to GNI & $\begin{array}{l}0.959 * * * \\
(0.279)\end{array}$ & $\begin{array}{l}0.810^{* * *} \\
(0.265)\end{array}$ & $\begin{array}{l}0.838^{* * *} \\
(0.252)\end{array}$ \\
\hline Reserves to GDP & $\begin{array}{c}-3.881 * * * \\
(1.369)\end{array}$ & $\begin{array}{c}-3.887 * * * \\
(1.399)\end{array}$ & $\begin{array}{c}-3.460 * * * \\
(1.242)\end{array}$ \\
\hline Log inflation & $\begin{array}{c}0.092 * * \\
(0.046)\end{array}$ & $\begin{array}{c}0.085^{* *} \\
(0.043)\end{array}$ & $\begin{array}{c}0.086^{* *} \\
(0.037)\end{array}$ \\
\hline Indefault & & $\begin{array}{c}0.115 \\
(0.086)\end{array}$ & $\begin{array}{c}0.120 \\
(0.077)\end{array}$ \\
\hline Regionexself & & & $\begin{array}{r}2.32 \mathrm{E}-04 * * \\
(7.71 \mathrm{E}-05)\end{array}$ \\
\hline Government revenue to GDP & $\begin{array}{l}1.378 \\
(1.057)\end{array}$ & $\begin{array}{c}0.660 \\
(1.113)\end{array}$ & $\begin{array}{c}0.795 \\
(1.067)\end{array}$ \\
\hline Public investment to GDP & $\begin{array}{l}-0.059 \\
(3.861)\end{array}$ & $\begin{array}{l}-1.146 \\
(3.548)\end{array}$ & $\begin{array}{l}-3.535 \\
(3.091)\end{array}$ \\
\hline Current expenditure to GDP & $\begin{array}{l}1.002 * * \\
(0.483)\end{array}$ & $\begin{array}{c}1.687 * * * \\
(0.620)\end{array}$ & $\begin{array}{c}2.096 * * * \\
(0.745)\end{array}$ \\
\hline \multicolumn{4}{|c|}{ (Specification Tests, p-value) } \\
\hline $\begin{array}{l}\text { Hansen-test of overidentification } \\
\text { Restrictions }\end{array}$ & 1.001 & 00 & 1.00 \\
\hline Arellano-Bond test for AR(1) & 0.0090 & 010 & 0.013 \\
\hline Arellano-Bond test for $\mathrm{AR}(2)$ & 0.4250 . & 476 & 0.431 \\
\hline
\end{tabular}

$\mathrm{N}=129$. Robust standard errors in parentheses. All columns include year and country fixed effects. Applying a two-tailed test, *indicates statistical significance at the 10 percent level, ** at the 5 percent level, and $* * *$ at the 1 percent level. 
Table 6. Correlation Matrix Deviations from Country Means

\begin{tabular}{|c|c|c|c|c|c|c|c|c|}
\hline Variable & Log Spread & Debt to GDP & $\begin{array}{l}\text { Reserve to } \\
\text { GDP }\end{array}$ & Log Inflation & Indefault & Regionexself & $\begin{array}{l}\text { Gov. } \\
\text { Revenue to } \\
\text { GDP }\end{array}$ & $\begin{array}{l}\text { Public } \\
\text { Investment } \\
\text { to GDP }\end{array}$ \\
\hline Debt to GNI & $\begin{array}{c}0.582 \\
(0.000)\end{array}$ & & & & & & & \\
\hline Reserves to GDP & $\begin{array}{l}-0.255 \\
(0.000)\end{array}$ & $\begin{array}{l}-0.0261 \\
(0.725)\end{array}$ & & & & & & \\
\hline Log inflation & $\begin{array}{l}0.3401 \\
(0.000)\end{array}$ & $\begin{array}{c}0.339 \\
(0.000)\end{array}$ & $\begin{array}{l}-0.3204 \\
(0.000)\end{array}$ & & & & & \\
\hline Indefault & $\begin{array}{c}0.366 \\
(0.000)\end{array}$ & $\begin{array}{c}0.294 \\
(0.000)\end{array}$ & $\begin{array}{l}-0.068 \\
(0.356)\end{array}$ & $\begin{array}{c}0.330 \\
(0.000)\end{array}$ & & & & \\
\hline Regionexself & $\begin{array}{c}0.330 \\
(0.000)\end{array}$ & $\begin{array}{l}-0.021 \\
(0.772)\end{array}$ & $\begin{array}{l}-0.069 \\
(0.350)\end{array}$ & $\begin{array}{l}-0.103 \\
(0.163)\end{array}$ & $\begin{array}{c}0.054 \\
(0.467)\end{array}$ & & & \\
\hline $\begin{array}{l}\text { Gov. Revenue } \\
\text { to GDP }\end{array}$ & $\begin{array}{c}0.064 \\
(0.390)\end{array}$ & $\begin{array}{l}-0.043 \\
(0.563)\end{array}$ & $\begin{array}{c}0.160 \\
(0.030)\end{array}$ & $\begin{array}{l}-0.290 \\
(0.000)\end{array}$ & $\begin{array}{c}0.142 \\
(0.054)\end{array}$ & $\begin{array}{c}0.072 \\
(0.329)\end{array}$ & & \\
\hline $\begin{array}{l}\text { Public Investment } \\
\text { to GDP }\end{array}$ & $\begin{array}{l}-0.032 \\
(0.667)\end{array}$ & $\begin{array}{l}-0.115 \\
(0.120)\end{array}$ & $\begin{array}{c}0.232 \\
(0.002)\end{array}$ & $\begin{array}{l}-0.091 \\
(0.217)\end{array}$ & $\begin{array}{l}0.092 \\
(0.212\end{array}$ & $\begin{array}{c}0.302 \\
(0.000)\end{array}$ & $\begin{array}{c}0.386 \\
(0.000)\end{array}$ & \\
\hline $\begin{array}{l}\text { Current Exp. To } \\
\text { GDP }\end{array}$ & $\begin{array}{c}0.354 \\
(0.000)\end{array}$ & $\begin{array}{c}0.287 \\
(0.000)\end{array}$ & $\begin{array}{c}0.182 \\
(0.013)\end{array}$ & $\begin{array}{l}-0.1554 \\
(0.035)\end{array}$ & $\begin{array}{c}0.098 \\
(0.186)\end{array}$ & $\begin{array}{c}0.050 \\
(0.501)\end{array}$ & $\begin{array}{c}0.578 \\
(0.000)\end{array}$ & $\begin{array}{c}0.117 \\
(0.113)\end{array}$ \\
\hline
\end{tabular}

Note: p-values in parentheses, below correlation coefficients. 


\section{REFERENCES}

Afonso, António, and Rolf Strauch, 2004, "Fiscal Policy Events and Interest Rate Swap Spreads: Evidence from the EU,” ECB Working Paper 303 (Frankfurt: European Central Bank).

Aisen, Ari, and Francisco José Veiga, 2005 "Does Political Instability Lead to Higher Inflation? A Panel Data Analysis," IMF Working Paper 05/49 (Washington: International Monetary Fund).

Alesina, Alberto, and Roberto Perotti, 1996, "Budget Deficits and Budget Institutions," NBER Working Paper 5556 (Cambridge, Massachusetts: National Bureau of Economic Research).

Alesina, Alberto, and others, 1999, "Fiscal Policy, Profits, and Investment," NBER Working Paper 7207 (Cambridge, Massachusetts: National Bureau of Economic Research).

Arellano, Manuel, and Stephen Bond, 1991, "Some Tests of Specification for Panel Data: Monte Carlo Evidence and an Application to Employment Equations," Review of Economic Studies, Vol. 58, No. 2, pp. 277-97.

Arora, Vivek, and Martín Cerisola, 2001, "How Does U.S. Monetary Policy Influence Sovereign Spreads in Emerging Markets," Staff Papers, International Monetary Fund, Vol. 48, No. 3, pp. 474-98.

Bayoumi, Tamin, and others, 1995, "Do Credit Markets Discipline Sovereign Borrowers? Evidence from U.S. States," Journal of Money, Credit and Banking, Vol. 27, No. 4, pp. 1046-59.

Block, Steven A., and Paul M. Vaaler, 2004, "The Price of Democracy: Sovereign Risk Ratings, Bond Spreads, and Political Business Cycles in Developing Countries," Journal of International Money and Finance, No. 23, pp. 917-46.

Bond, Stephen, 2002, "Dynamic Panel Data Models: A Guide to Micro Data Methods and Practice," Portuguese Economic Journal, Vol. 1, pp. 141-62.

Calvo, Sara, and Carmen Reinhart, 1996, "Capital Flows to Latin America: Is There Evidence of Contagion Effects?” in Private Capital Flows to Emerging Markets, ed. by G. Calvo and others (Washington: Institute for International Economics).

Cantor, Richard, and Frank Parker, 1996, "Determinants and Inputs of Sovereign Credit Ratings," Economic Policy Review, Federal Reserve Board of New York, Vol. 2, pp. 37-53. 
Catão, Luis, and Sandeep Kapur, 2004, "Missing Link: Volatility and the Debt Intolerance Paradox,” IMF Working Paper 04/51 (Washington: International Monetary Fund).

Catão, Luis, and Bennett Sutton, 2002, "Sovereign Defaults: The Role of Volatility," IMF Working Paper 02/149 (Washington: International Monetary Fund).

Ciocchini, Francisco, and others, 2003, "Does Corruption Increase Emerging Market Bond Spreads?” Working Paper 2003/03 (New York: Cornell University).

Cline, William, and Kevin J. S. Barnes, 1997, "Spreads and Risk in Emerging Markets Lending," IFF Research Paper 97, No.1 (Washington: Institute of International Finance).

Dell'Ariccia, Giovanni, and others, 2002, "Moral Hazard and International Crisis Lending: A Test," IMF Working Paper 02/181 (Washington: International Monetary Fund).

Detragiache, Enrica, and Antonio Spilimbergo, 2001, "Crises and Liquidity: Evidence and Interpretation,” IMF Working Paper 01/02 (Washington: International Monetary Fund).

Edwards, Sebastian, 1984, “LDC's Foreign Borrowing and Default Risk: An Empirical Investigation," American Economic Review, Vol. 74, No. 4, pp. 726-34.

Edwards, Sebastian, 1986, "The Pricing of Bonds and Bank Loans in International Markets: An Empirical Analysis of Developing Countries' Foreign Borrowing," European Economic Review 30, No. 3, pp. 565-89.

Eichengreen, Barry, and Ashok Mody, 1998a, "Interest Rates in the North and Capital Flows to the South: Is there a Missing Link?'International Finance, Vol. 1, No. 1, pp. $35-57$.

_ 1998 b, "What Explains Changing Spreads on Emerging-Market Debt: Fundamentals or Market Sentiment?” NBER Working Paper 6408 (Cambridge, Massachusetts: National Bureau of Economic Research).

Eichengreen, Barry, and Richard Portes, 1986, "Debt and Default in the 1930s: Causes and Consequences,” European Economic Review, Vol. 30, pp. 599-640.

Gelos, R. Gaston, and others, 2004, Sovereign Borrowing by Developing Countries: What Determine Market Access? IMF Research Workshop, October 23-24, 2003.

Jahjad, Samir, and Vivian Yue, 2004, "Exchange Rate Policy and Sovereign Bond Spreads in Developing Countries," IMF Working Paper 04/210 (Washington: International Monetary Fund). 
Kaminsky, Graciela, and Sergio Schmukler, 1999, "What Triggers Market Jitters?: A Chronicle of the Asian Crisis," Journal of International Money and Finance, Volume 18, No. 4, pp. 537-60.

—_, 2001, "Emerging Markets Instability: Do Sovereign Ratings Affect Country Risk and Stock Returns?” World Bank Research Working Paper 2678 (Washington: World Bank).

Kaminsky, Graciela, and others, 1997, "Leading Indicators of Currency Crises," IMF Working Paper 97/79 (Washington: World Bank).

Kaminsky, Graciela, and Carmen M. Reinhart, 2000, “On Crises, Contagion, and Confusion,” Journal of International Economics, Vol. 51 (June), pp. 145-68.

Lane, Timothy, and Steven Phillips, 2000, "Does IMF Financing Result in Moral Hazard?" IMF Working Paper 00/168 (Washington: International Monetary Fund).

Manasse, Paolo, and others, 2003, "Predicting Sovereign Debt Crises," IMF Working Paper 03/221 (Washington: International Monetary Fund).

Manasse, Paolo, and Nouriel Roubini, 2005, "Rules of Thumb for Sovereign Debt Crises," IMF Working Paper 05/42 (Washington: International Monetary Fund).

Mauro, Paolo, and others, 2002, "Emerging Market Spreads: Then Versus Now," The Quarterly Journal of Economics, Vol. 117, No. 2, pp. 695-720.

McGuire, Patrick, and Martijn Schrijvers, 2003, "Common Factors in Emerging Market Spreads,” BIS Quarterly Review, pp. 65-78.

Min, Hong, 1998, "Determinants of Emerging Market Bond Spread: Do Economic Fundamentals Matter?” World Bank Working Paper 1899 (Washington: World Bank).

Reinhart, Carmen, 2002, “Default, Currency Crises, and Sovereign Credit Ratings,” World Bank Economic Review, Vol. 16, No. 2, pp. 151-70.

Reinhart, Carmen, and others, 2003, “Debt Intolerance,” NBER Working Paper 9908 (Cambridge, Massachusetts: National Bureau of Economic Research).

Roodman, David, 2005, Xtabond2: Stata Module to Extend Xtabond Dynamic Panel Data Estimator. (Washington: Center for Global Development). Available via the Internet: http://econpapers.repec.org/software/bocbocode/s435901.htm

Sobrinho, Nelson F. Souza, 2004, "Sovereign Risk in Developing Countries," Mimeo, (Los Angeles: University of California, UCLA). 
Uribe, Martin, 2002, “A Fiscal Theory of Sovereign Risk,” NBER Working Paper 9221 (Cambridge, Massachusetts: National Bureau of Economic Research).

Zhang, Xiaoming Alain, 1999, "Testing for 'Moral Hazard' in Emerging Markets Lending," IIF Research Paper 99/1 (Washington: Institute of International Finance). 